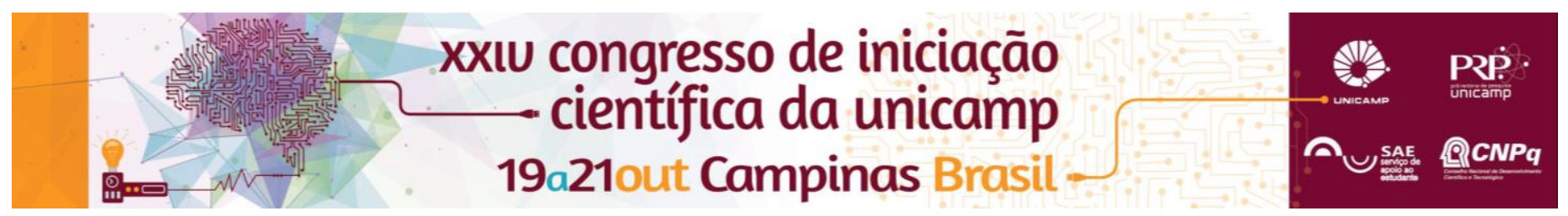

\title{
A REPRESENTAÇÃO DA MULHER BRASILEIRA EM MONUMENTOS HISTÓRICOS: Uma análise a partir das esculturas públicas da cidade de São Paulo.
}

\author{
Emanuelle Cruz, Janaina Xavier, Monique Pinho, Vanessa Motoso*
}

\begin{abstract}
Resumo
Os monumentos históricos, desde a Antiguidade Clássica, estiveram inseridos no âmbito público. Os bustos têm o propósito de eternizar a memória coletiva de uma sociedade e empoderar essa notória personalidade através dos tempos. Esse trabalho postula o estudo de três figuras femininas esculpidas em bustos na cidade de São Paulo, deixando registrado seu legado durante o século XX, analisando a história dessas mulheres e o atual estado de conservação e preservação de seus monumentos na tentativa de compreender a presença dos mesmos no espaço urbano.
\end{abstract}

Palavras-chave:

Mulheres; História; Monumentos Históricos; Preservação.

\section{Introdução}

Essa pesquisa apresenta o prelúdio dos resultados de um Trabalho de Conclusão do Curso de Licenciatura em História do Centro Universitário Adventista de São Paulo (UNASP). O objetivo desse estudo é investigar os monumentos históricos e, mais especificamente, os bustos da pianista Antonieta Rudge (1885-1974), da educadora Carolina Ribeiro (1892-1982) e da médica e política Carlota Pereira de Queiroz (1892-1982), obras do artista Luiz Morrone, na cidade de São Paulo, inseridas no contexto da História da Mulher no Brasil durante o século $\mathrm{XX}$. Por meio de estudos bibliográficos e visitas técnicas buscou-se contribuir para o entendimento do papel da mulher na sociedade brasileira no século XX, atribuindoIhe a valorização, percepção e destaque por intermédio dos bustos; Auxiliar no ofício do historiador ao perceber a confluência entre a História e os monumentos públicos e sua valia para a sociedade contemporânea; E considerar o período em que estes monumentos foram produzidos e seu atual estado de preservação e inserção no contexto da cidade.

\section{Resultados e Discussão}

As esculturas públicas interagem, direta ou indiretamente, com seu espaço. De alguma forma elas mantêm a história e a memória coletiva que por muitas situações se deteriora fisicamente com a perda das obras ou metafisicamente no esvaziamento dos valores sentimentais. As esculturas públicas são uma forma de convidar a população para conhecer a si mesmo, sua história e o que são hoje (FUREGATTI; VALLE, 2014). A teórica Choay (2011) analisa as definições sobre os monumentos históricos e sua valorização em decorrência do tempo, como os profissionais ao longo da história lidaram com as questões culturais e as regras empregadas para preservação dos mesmos. Le Goff (2003) considera os monumentos históricos como documentos, ligando-se ao poder de perpetuação, voluntária ou involuntária, das sociedades históricas (é um legado à memória coletiva) e o reenviar a testemunhos que nem sempre ou necessariamente são escritos. $O$ estudo sobre o gênero feminino tem ampliado cada vez mais seu campo de pesquisa, em função da inserção das mulheres em diversificados espaços da sociedade. Esse interesse é importante para que sejam revistos estereótipos inculcados na mulher, como por exemplo, rotulá-la de auto sacrificada ou submissa sexual. Para que esse comportamento seja desfeito é preciso analisar e reexaminar a história da mulher, mas não sob os olhos de homens, e sim nas muitas bibliografias sobre as mulheres, escritas na visão delas (DEL PRIORE,1994). Essa mentalidade foi mais distendida pela Escola de Annales, fundada em 1929, com mais precisão na segunda e terceira geração, com a intitulada Nova História. A história das mulheres foi ocultada e desprezada durante muito tempo, pela falta de informações e a proliferação de um imaginário irreal sobre ela. As mulheres são mais imaginadas do que descritas ou contadas, e fazer a sua história, é antes de tudo, inevitavelmente, chocar-se contra este bloco de representações que as cobre e que é preciso, necessariamente, analisar como elas mesmas as viam e as viviam (PERROT, 2005).

\section{Conclusões}

Dado o exposto, a relação estabelecida por essa pesquisa, é a importância dos bustos e estátuas femininas, como um documento e monumento à memória dessas personalidades, ressaltando assim a história delas na sociedade brasileira e destacando a relevância dos monumentos na sociedade contemporânea.

\section{Agradecimentos}

A Deus pela capacidade concedida para realizar esse estudo. Ao UNASP e o Curso de História. A Prof ${ }^{a}$ Me. Janaina Xavier pelo esforço e dedicação em orientar essa pesquisa. $\mathrm{E}$ aos familiares e demais colegas pelo apoio nessa investigação.

CHOAY, Françoise. A Alegoria do Patrimônio. São Paulo: Estação da Liberdade, 2001.

DEL PRIORE, Mary. A mulher na história do Brasil. $4^{\circ}$ ED. São Paulo: Contexto, 1994

FUREGATTI, Sylvia; VALLE, Marco Antônio Alves. As esculturas públicas e a cidade contemporânea. Campinas: Instituto de Artes, UNICAMP, 2014.

LE GOFF, Jacques. História e Memória. Campinas, SP: Ed. UNICAMP, 2003. PERROT, Michelle. As Mulheres ou os silêncios da história. Tradução de Viviane Ribeiro. 1. ed. Bauru: EDUSC, 2005. 